\title{
The Research of Cultural Impact of Japan on Changchun During the Manchukuo Period in China
}

\author{
Jing Huang ${ }^{1, *}$ Qing Shen ${ }^{1}$
}

\author{
${ }^{1}$ Northeast Asia Enterprise Cooperation and Innovation Development Research Center, Jilin International \\ Studies University, Changchun, Jilin 130117, China \\ *Corresponding author. Email: sudy20@163.com
}

\begin{abstract}
The Manchukuo was a pseudo-government mainly established by the adherents of the Qing Dynasty after the Japanese occupied the three northeastern provinces after the September 18th Incident to divide China, and the Chinese government never recognized its legitimacy. Changchun was once identified as the "capital" of the Manchukuo by the Japanese invaders. Pu Yi, a representative of the pseudo-regime, was active here for nearly 14 years. From the perspective of Changchun, this paper first discusses the general situation of Changchun, the culture of Changchun in the late Qing Dynasty and the outbreak of the September 18th Incident, and then analyzes the influence of Japan on Changchun culture during the Manchukuo period from the perspectives of education, literature, and religion.
\end{abstract}

Keywords: Manchukuo, education, literature, religion, culture shock

\section{INTRODUCTION}

Changchun is the capital of Jilin Province and an important industrial base with convenient transportation, running through the three northeastern provinces and being in a central position. Changchun is one of China's earliest old industrial bases, as well as China's earliest automobile industry base and film base. Famous enterprises such as China FAW Group, Changchun Film Studio, Chang Chun Sheng Wu Zhi Pin Yan Jiu Suo were born here, and Changchun can be called the cradle of applied chemistry and biological products industry. In modern times, Changchun was once the capital of the Manchukuo, namely Hsinking.

\section{OVERVIEW OF CHANGCHUN IN THE LATE QING DYNASTY AND THE OUTBREAK OF THE SEPTEMBER 18TH INCIDENT}

Changchun was built in the fifth year of Jiaqing. Before that, Changchun was only a small town under the general of Jilin. It was not changed until Russia and Japan invaded. The Changchun culture at the end of the Qing Dynasty mainly consisted of the Han nationality culture brought by the people of the Central Plains in the Ming and Qing dynasties who "braved the journey to Northeast". In the early Qing Dynasty, Kangxi adopted the Northeast blocks in order to protect the Manchu culture in "The Land of Dragon Rising" of the Northeast from Chinesization. The long-term closure of the Northeast didn't allow for new cultural development. The arrival of Han nationality culture here was a cultural shock. Regarding the culture of the late Qing Dynasty, it was roughly the same as the culture of the Central Plains of China at the same time: it was mainly based on Confucianism, with the heart of "courtiers of imperial court" in it; the philosophy inherited the ideas of Confucius, Mencius, Lao Zi, Zhuang Zi, Wang Yangming, etc.; most of the religions believed in were Buddhism, Lamaism, etc. The imperial examination system was also practiced here. However, most of the people living in the Northeastern region with superior living conditions were mostly the Manchu nobles, so the phenomenon of officials within close relatives is still more than the phenomenon of literati's reading for the imperial examination; because the Han people and the Manchus have been merging together for more than 300 years, Manchu and Chinese have been combined in the late Qing Dynasty. Few people speak pure Manchu, but the Northeast dialect with Manchu elements. Although Changchun in the late Qing Dynasty was not the place for economic and cultural development at that time, it still retains the traditional cultural ideas and life concepts of the Chinese people. 
The Japanese Kwantung Army entrenched in Northeast China for a long time. In 1931, they launched the September 18 Incident. After receiving the notice, Chiang Kai-shek informed the Northeast Army stationed in the Northeast to adopt a non-resistance policy. But not all people in the country didn't resist this catastrophe. A small number of people fought bravely, but in the end they all failed. Japan began its war of aggression against China.

\section{THE ESTABLISHMENT OF THE MANCHUKUO AND THE REASONS FOR THE ESTABLISHMENT OF THE CAPITAL OF ChangChun}

The term "railway accessorily" is a special concept in modern China. It was originally different from the "concession territory" of the imperialist powers in China. However, in the modern history of Northeast China, there are much "railway accessorily", and Changchun has one. After the Russo-Japanese War in 1905, Japan transferred all rights and interests related to the Middle East Railway in southern Changchun, which was surrendered by the defeat of Russia, into the scope of the Manchurian railway accessorily. By then, Changchun was continuously eroded by Japan.

Japan's economic strength was strong and it was the main local economy, and the development of Chinese national capitalism was difficult. "Boycott of Japanese goods", "strikes to defend rights" and other forms of protest didn't cause much damage to Japan. The reason was that the financial and commercial management rights were in the hands of the Japanese. This deepened ethnic conflicts to a greater extent.

Chiang Kai-shek's policy of non-resistance allowed the Japanese invaders to quickly occupy the entire Northeast including the four provinces of Liaoning, Jilin, Heilongjiang, and Rehe and eastern Inner Mongolia. On March 9, 1932, the last emperor $\mathrm{Pu} \mathrm{Yi}$ was instigated by Japan and established the "Manchukuo", known as the puppet regime in history. After that, Japan signed the "Japanese-Manchurian Protocol" in Changchun, officially recognizing the "Manchukuo". As part of the Northeast region, Changchun was designated as the pseudo-capital by Japan.

Regarding why Japan wanted to establish a "pseudo-capital" in Changchun, there are the following conditions: first, Changchun, like Shenyang, Harbin, Jilin and other cities, has relatively convenient transportation. Changchun is in the central area of Northeast China. Compared with cities such as Harbin, Shenyang, and Jilin which may be more south or north, it is more conducive to control and more convenient for transportation. Second, Changchun, like Shenyang, Jilin and other cities, has been operated by Japanese colonialists for several years. It has a large area of railway accessorily, and rights of consulates, residency and commercial tenant, making it easier to operate. Third, Changchun City has a large territory and has the advantage of low land prices, facilitating the Japanese invaders to further plunder resources.

In short, the selection of Changchun by the Japanese imperialists as the capital of the Manchukuo colonial government was completely based on their established aggressive policy. This was very conducive to its goal of occupying the Northeast for a long time, then invading China and Southeast Asian countries in the south, and attacking the Soviet Union in the north.

\section{THE CULTURAL INFLUENCE ON ChangChun}

The Chinese during the Manchukuo period were oppressed by the Japanese military force, and were forced to accept foreign cultures, and colonial ideas the people were repeatedly brainwashed with colonial ideas. Enslaving education, the "new educational system" education policy, "Manchukuo Chinese literature", religious control, etc. were all ways of their cultural aggression. Changchun, as the pseudo-capital, became an important city for propagating these cultural ideas. The city suffered severe persecution, which imprisoned people's ideology.

\section{A. Enslaving education and the "new educational system" education policy}

Japanese imperialism wanted to replace China's traditional culture with its own culture and ideas, so as to better control people spiritually. Therefore, they promoted the reform of education, and established a colonial system and institutions to comprehensively promote enslaving education in order to better control the Kanto Area. In response to the active ideological and political activities of schools in the Northeast, the Japanese aggressors closed, occupied, and destroyed a large number of schools, such as turning the schools into military command headquarters, and burning them down with the crime of "communist". The Japanese puppet regime didn't allow schools to fly the Chinese flag, didn't allow the appearance of the words "Republic of China", didn't allow the use of Chinese textbooks, and didn't even allow people to say that they were Chinese. In addition, they promoted the "kingly way education", implemented a policy of keeping the people in ignorance, abolished national teaching materials, and advocated feudal ethical code. They only allowed schools to use "The Four Books" and "The Classic 
of Filial Piety" as teaching materials. Later, in accordance with the spirit of the "Manchukuo Declaration on the Founding of a State", they organized the compilation of teaching materials in an attempt to obliterate the national consciousness of the young people in the Northeast and make them forget their homeland. Furthermore, they promoted emperor education to educate faithful and upright citizens. After the July 7th Incident, the Japanese puppet regime adopted the "Huiluan Xunmin Edict" as the educational concept of the Manchuria, and promulgated it in the form of "decree" to promote the "imperial education". Japan's education in the colonies had two goals: first, such enslaved education could make the "Manchukuo" more permanent. It would also spend extra time instilling the emperor's thoughts into the people, and this behavior became a breakwater to prevent anti-Manchu thoughts and actions. Second, the education policy of the "Manchukuo" was to allow talents and labor to fully develop in the Japanese colonial areas.

The colonial enslaving education promoted by the Japanese puppet regime caused tremendous spiritual damage to the people of Northeast China, and was an important part of the Japanese invaders' obliteration of Chinese national thinking and colonial rule.

On May 2, 1937, the Manchukuo announced the "new educational system" education policy, which was the top priority of the colonial education system.

The characteristics of the "new educational system" are as follows: first, the "Huiluan Xunmin Edict" was used as the basis for the basic concept of "Manchukuo" education, positioning laws and regulations to restrict everything in the school education system. From then on, the colonial education policy that instilled the emperor's ideology into the people of the Northeast was established as the colonial education system, and it was fully implemented from elementary education to higher education. Second, the decline in teaching quality was due to the shortening of academic years and the emphasis on "industrial education", which reduced the quality of teaching. Due to industrial education, the school reduced the class hours of general subjects, and the systematic knowledge teaching of humanities and other subjects was greatly restricted. Third, the school taught Japanese to students, and defined it as the national language, and the teaching time was $3 \%$ of the day's study time.

The new educational system took the development of "industrial education" as the main theme, so as to cultivate the spirit of labor education and love of hard work. It changed from the original sixteen educational system to a thirteen educational system, which shortened the time of study, so as to provide more labor productivity for the Manchukuo Empire. The new educational system focused on experimentation and labor, mostly cultivating labor-oriented talents and increasing the social application rate. In addition, the educational system of secondary vocational schools opened under the guidance of the new educational system was only two or three years. The purpose was to train the elementary labor force as a supplement to the national colleges and universities, and to develop Northeast China more quickly.

The "new educational system" policy during the Manchukuo period greatly affected the development and construction of schools, and became the epitome of the failure of education in the Changchun era. It deprived the people of educational opportunities and reduced their knowledge level. It was carried out against the background of suppressing resistance inside and outside the school and completely obliterating freedom of speech, and it had a doubly negative effect on the people's thinking.

\section{B. Chinese literature of "Manchukuo"}

After the establishment of the Manchukuo, Changchun was playing the role of the national capital of the "Manchukuo" as one of the "Hsinking" and "astedader akabibi". At that time, the central administrative organ of colonial rule was built here, and its posture of cultural center attracted various groups of writers and publishing organizations. This provided a certain prerequisite for the recovery and development of literary activities during the enemy occupation that may make Changchun culture an "official" culture.

In 1937, Chinese literary activities conducted by scattered groups throughout the "Manchukuo" were very active. The outbreak of the Lugou Bridge Incident made the Chinese who were in the "Manchukuo" also be forced like their compatriots to fight together. The young writers residing in Northeast China couldn't break through the harsh cultural dictatorship and learn from left-wing literature, nor could they approach the national and ethnic themes in the same period. Therefore, they sought more spiritual resources from the literature of the May Fourth Movement, and the same was true with main literary groups in Changchun in the mid-occupied period - Articles Printing and Publishing Guild and Art and Literature Affairs. The Articles Printing and Publishing Guild included more than ten people including Liang Shanding, Wu Lang, Wu Ying, Jin Yin, and Mei Niang. Unfortunately, the "Articles Periodical" was not released in the end, but more series of writers were published in this format. They were based on the principle that "literature was a tool for 
educating the masses and a tool for understanding reality" to echo with "Articles Periodical" in the field of literature. Through their strokes, they truly exposed Japan's spiritual oppression of the people in the Northeast and colonial routines, formed an "exposing truth" writing style, and became an irresistible force for anti-colonization and the pursuit of national unity.

Before 1937, Changchun's cultural dissemination was only through the newspaper supplement, and it was turned into a literary publication until the later release of "Ming Ming". The "Manchukuo" literary world truly entered the era of literary magazines and offprint releases, and Changchun's "fan literature" thus formed the symbol phenomenon of literature in the occupied area of Northeast China.

Within the years after the founding of "Manchukuo", the literary activities of the "Manchukuo" Japanese still maintained their previous activities. However, as the number of "immigrants" of Japan increased, comprehensive literary and artistic magazines that published novels and operas began to appear. Its pioneer was the fan magazine "Color" founded by Aoki. After this: the Manchurian Cultural Association, the earliest national literary organization of "Manchuria" was born. With the prolonged Sino-Japanese War, the government's involvement in the Manchurian literary movement also deepened. Under the control of the Kwantung Army and the government, literary workers were mobilized to go to factories and rural areas or participate in military exercises, and almost all their freedom of expression was lost. The people were driven into the Sino-Japanese War, to the "Great East Asian War", and the "Manchurian Literature" movement entered a period of rampant rhetoric to encourage fighting spirit.

\section{Religious control}

Before the Japanese occupation of Northeast China, the religions in Northeast China mainly included Buddhism and Lamaism. After 1932, all religious activities of the Manchukuo were placed under the strict control of the Japanese puppet regime authorities as well as the military, police, constitution, and special authorities, forming a strict religious rule system. Japan dispatched Japanese monks to the major temples in Northeast China to promote the content of "Japanese-Manchurian friendship, Japanese-Manchurian exchanges", and asked Buddhist monks to inspect. Exchange of scholars and monks in Japan and Manchukuo promoted the spread of Japanese Buddhism. The Shanguo monk at Banruo Temple in Changchun was a typical example who was roped, manipulated and used as a top character of religions by the Japanese puppet regime.
The Japanese monk Genmei Tsuzuki in Changchun Banruo Temple was the general representative of Japanese monks in the "Manchuria" temples. Taniguchi Jisho, who served as the vice-chairman of the "Manchukuo" Buddhist General Assembly, and the Finance Minister Fujimoto, and the Chief of Staff Tianerhao, held the power of the church. The Japanese Kwantung Army directly controlled the enlightenment work of the Manchukuo. The Chief of Staff of the Kwantung Army, Sozaburo Sakamoto and Kotaro Ueda concurrently served as the chairmen of the Manchukuo Buddhist Dharmapalas Society, and directly participated in and directed Buddhist activities. In 1941, the Japanese puppet regime also began to "educate" the "national soldiers" enlisted in the army, using the idea of "Great East Asia Jihad" to deceive people. They instructed monks from the good consequence organization and believers to come to the station to welcome the bones of the Japanese army killed by the antiJapanese armed forces, and to hold a memorial service for the dead.

These compulsive religious tactics were undoubtedly a complete indoctrination of the theory of invasion and occupation to the minds of the people of Changchun, and they taught the people to become loyal and obedient citizens of the empire. They also implemented the fascist repressive rule from beginning to end. The Japanese imperialists criminally carried their own "Amaterasu" in an attempt to brainwash the people and make them cater to Japan's "ancestors." Japan's cutting-edge violent behavior didn't make the people give in, and the people didn't agree with the legal status of the Japanese Manchukuo regime. However, the ruthless methods of the Japanese empire still brought heavy blows and disasters to the people in Changchun and even the Northeast region in their spirit and life.

\section{CONCLUSION}

Japan had a profound and indelible influence on Changchun in modern times. During the "Manchukuo" period, Japan attempted to "brainwash" the education, literature, and religion of Changchun to control the minds and hearts of Chinese people. Culture is the soul of a city, and cultural aggression is a blockage and destruction of Changchun's native culture. Although the word "pseudo" left by modern Japanese colonists has a colonial color, the culture is a cultural relic after all. It shouldn't disagree with this past history because of lack of confidence and difficulty in inspiring national pride. Colonial sites should not be allowed to become the representative color of Changchun. It's necessary to allow the nation to establish a righteous spirit, not tolerate foreign countries everywhere, and have national integrity. Chinese people shouldn't forget history, and they must enter 
a new era of "peace and development" and pursue eternal peace. Changchun during the end of the Qing Dynasty has long been away from people, but the city's spirit of "magnanimity, tolerance and selfimprovement" is still what people pursue. In the face of the influence brought by the culture, the most important thing is to be familiar with the real past and the vicissitudes of life behind it, and to sort out the correct concepts and standards for observing them. Chinese people need to take the essence and discard the dross.

\section{References}

[1] Jiang Kun. Research on Japan's Cultural Infiltration Strategy in Northeast China During the Manchukuo Period [J]. The Border Economy and Culture, 2020(08):51-53. (in Chinese)

[2] Li Feng. Japan's Cultural Rule and Enslaving Education in Northeast China During the Manchukuo Period [J]. Journal of Foreign Studies, 2019(02):105-110+120. (in Chinese)

[3] Wang Yue, Feng Ya. The Nationalist Features of Literature in the Enemy Occupation of Northeast China [J]. Literary and Artistic Contention, 2014(04):120-125. (in Chinese)

[4] Zhang Rui. The "Great Northern Newspaper" and the Japanese Utilization and Propaganda of Chinese Traditional Religions During the Manchukuo Period [J]. Journal of Lanzhou Institute of Education, 2015, 31(12): 12-14. (in Chinese)

[5] Li Hui. The Main Activities and Influence of Japanese Shintoism in the Northeast During the Manchukuo Period [J]. Lantai World, 2012(22):44-45. (in Chinese)

[6] Chen Wenxue. The Religious Invasion of Northeast China by Japanese Colonists During the Manchukuo Period [D]. Heilongjiang University, 2015. (in Chinese)

[7] Jiang Lei, Chen Xi. The Underground Writing and Postwar Presentation of Resistance Literature During the Manchukuo Period [J]. Social Science Front, 2019(03):264-269. (in Chinese)

[8] Bao Xueju. "A Tale of Two Cities" in the Manchukuo Literature - The Literary Scenes of Harbin and Changchun During the Period When the Northeast Was Occupied [J]. Literary Review, 2017(02):90-94+120. (in Chinese) 